\title{
The Mapping of Core Competence of National Exam in South Central
} Timor

\author{
Ch. Krisnandari Ekowati ${ }^{1}$, Muhammad $\mathrm{Ardi}^{2}$, Muhammad Darwis ${ }^{1}$, H. M. D. Pua Upa ${ }^{2} \&$ \\ Gufran Darma Dirawan ${ }^{2}$ \\ ${ }^{1}$ Faculty of Education, Nusa Cendana University, Indonesia \\ ${ }^{2}$ Department of Environment Education, Makassar State University, Indonesia
}

Correspondence: Gufran Darma Dirawan, Makassar State University, Indonesia. E-mail: gufrandarma@yahoo.com

Received: June 16, 2014 Accepted: July 29, 2014 Online Published: September 28, 2014

doi:10.5539/ies.v7n10p130 URL: http://dx.doi.org/10.5539/ies.v7n10p130

\begin{abstract}
The purpose of this study were to determine the mapping of core competencies of National Examination in several subjects at senior high school (SMA/MA) in South Central Timor (TTS) and to understand causes and find solutions for the local government South East Timor (NTT) in managing their education system. This study was also expected to boost the ranking of high school graduation (SMA/MA) in NTT. The numbers of sample that conduct in this research were 22 schools, taken by using stratified random sampling technique by considering the characteristics of the proportion of the population in the area of study. The approach used is a descriptive research that trying to find data in each competency tested in 2009 and 2010 and analyzed by using the mapping of the standard competencies. The procedures of research are the study documentation, implementation of teacher ability test, questionnaire, Focused Group Discussion (FGD) and observation. The results showed: there are two factors that cause low achievement in basic competency examination subjects: Firstly, static factors, the problem is not the existence of (a) the science laboratory, (b) the school library, (c) the field laboratory, (d) English language laboratories, small amount school operational funds, the low participation of school committees. Secondly, dynamic factors, that consist of ; the low cognitive teachers because teachers are not teaching subjects in related to their home-based academic, lack of innovation in learning and lack of practice hours for students Therefore, the planned a model of problem solving are; (1) increasing teachers community programs (MGMPs) through the coaching program to supports the students in achieving passing grade standard, (2) improving the monitoring of learning in the classroom, (3) assisting teachers in classroom learning process by improving qualification of the teachers. This study should be continued in the form of community service that can involve all stakeholders i.e.; school principals, teachers, school committees and community.
\end{abstract}

Keywords: national examination, mapping, standard competency

\section{Introduction}

The purpose of the National Examination (UN) in senior high school (SMA) are Firstly, to measure the achievement of student learning outcomes, Secondly, to measure the quality of education at the national, provincial, district/city and Thirdly, to assess and control organization of education in the level of district / city. In this function it means of quality control nationally system of education. The main problems of the UN and graduation criteria stipulated in the standard operating procedures (SOP) that applied nationally without considering teachers ability in learning process (BSNP, 2010). In a way, appearing in a wide variety of shortcomings in the implementation of the National Examination that last three years, the Ministry of Education has involved universities to help implement the National Examination in the field as an independent team. The results are quite significant in many provinces over which gets the category from gray to white, meaning that the higher the level of honesty. Special to the Province of East Nusa Tenggara, always get a white predicate the lowest level in the implementation of the National Examination last three years, but the ranking of graduation is 33 out of 33 provinces in Indonesia (Balitbang, 2010).

Furthermore, the percentage of completion for district South Central Timor (TTS) is $36.03 \%$ of students did not pass the science subjects, $22.99 \%$ of students did not pass the social science subjects and $19.40 \%$ of students did 
not pass the English Department (Balitbang, 2011). By looking at the fact above, it can be stated that the lack of graduate-level high school students for three majors subject still relatively high. The results of preliminary observations also indicated that there were still problems in basic examination competency in several subjects who have not mastered the students to pass the examination. This fact rose the question "why the standard competency is not achieved by the students". On the other hand, this research is become very important to understand the overall quality of education system in NTT that relate to school quality. Meanwhile, school quality is a multidimensional concept that is not only associated with one particular aspect of the school. Quality of schools can be seen from the level of the school and the feasibility of implementation as well the performance of the students that refers to the school's main components include components: (1) curriculum and the learning process, (2) the administration and management of the school, (3) infrastructure, (4) organization and school institution, (4) human resources, (6) financing, (7) students, (8) community participation, and (9) government. (Chamidi, 2005)

There are three important things that assessed in this study include: (1) what is the basic competencies by high school students in several subjects in the National Examination TTS? (2) What factors are causing the student has not mastered the basic competencies in subjects in the National Examination TTS? (3) How to create alternative solution model that can be implemented in district South Central Timor (TTS).

\section{Research and Methods}

The research approach is using descriptive methods, to seeks, obtain and analyze data on mapping student's standard competencies that have not been mastered by high school students in several subjects at TTS. Data of students tested in each competency at each school on the implementation of the UN in 2009 and 2010 were analyzed and grouped by level of competencies which are low absorbance.

The study population was all SMA/MA in TTS as many as 22 schools, while the techniques used stratified random sampling. This sampling conducted stratified by considering the characteristics of the population and the proportion of schools in one area. Sample was determined based on qualifications and low school achievement based on the results of the UN TTS. Further research procedures are (1) observation and documentation, (2) the implementation of a teacher competency test, (3) questionnaire, (4) Focused Group Discussion (FGD).

The data obtained is really valid, and then the technique of triangulation is to compare test data with interview data on students and teachers, and observation data learning implementation in the classrooms, as well as data obtained through focus group discussions. Research instruments were used: (1) guidelines and maps UN competency test, (2) questionnaire motivation and interest of students, (3) test the ability of students about the UN test, (4) questionnaire of teachers teaching experience, (5) observation. The data that have been collected will be analyzed by descriptive qualitative inductive method. Each type of data obtained from each school, will be tabulated, and then performed to obtain the specification and interpretation of findings. Data analysis begins by analyzing the results of the UN in the last 2 years to do a basic competency mapping. Furthermore, we will analyze test data, observations and focus group discussions with the primary goal is to identify the causes of the inability of students achieving standard competency subjects on National Exam. Of the causes and map competencies analyzed, will be examined to look for the problem-solving model of implementation. Complete study procedures to the analysis of the data depicted in the following diagram. 


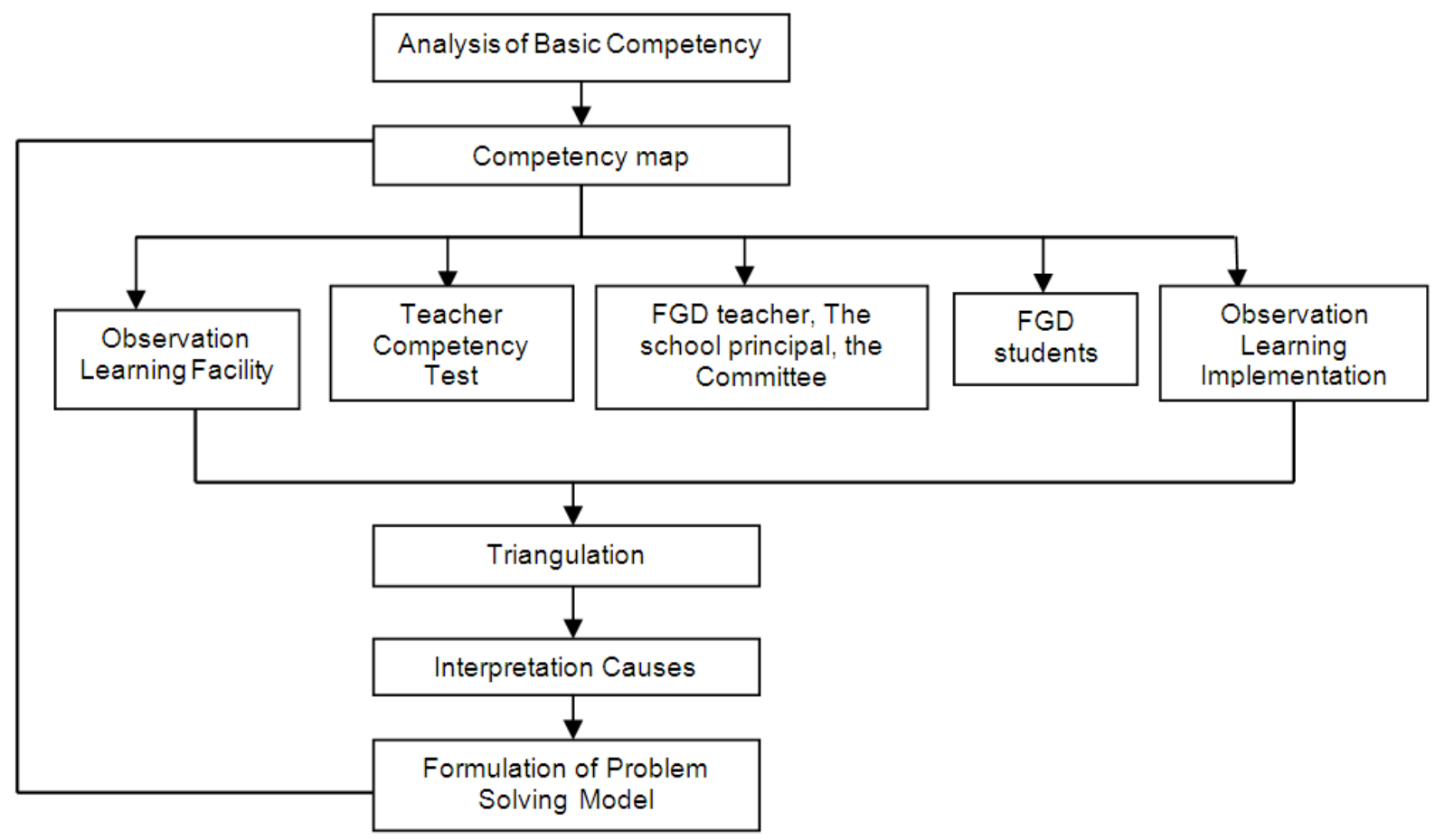

Figure 1. Flowchart research and methods (Sources: Garak, 2006; Moleng, 2003; Lehmann, 1990)

\section{Results and Discussion}

Mapping Research and Development Quality Education (PPMP) was held in South Central Timor (TTS) East Nusa Tenggara (NTT). The total number of researchers involved as many as 13 (thirteen) members, consisting of 10 (ten) lecturers from the Faculty of Education Nusa Cendana University (UNDANA), and 3 enumerators who have an undergraduate teaching assistant level. The number of members of the researcher no longer compatible with the proposed proposal, this is because the lead researcher felt the need to recruit more enumerator / members of other researchers in accordance with the subject areas to be studied. Therefore, it coupled with subject areas of Physics, Chemistry, Indonesian, Sociology, Geography, all of whom are faculty of Education UNDANA.

In accordance with the method chosen, the initial step is to determine the sample schools that have average under 60 values of science and social subjects. Then it gained 9 SMA which are SMA Negeri 3, SMA 2 SMA PGRI, Christian High School, SMA Islam and pure private high school. Of the nine schools, the data is taken by looking at 9 subjects that have low absorptive capacity. Moreover, it was tabulated, by grouping of material or topics students have not measured before.

After it was measured, the next step was grouping methods by looking for difficult topic on each subject and designed a test question for the teacher. Problem description is made in the form prepared by competent lecturers with these subjects. The aim of the test of professional competence of the teacher is expected to get an idea of the cause of students' difficulties in understanding certain subject, with the assumption that if the same teacher test scores with students means teachers to be one of the causes of low student ability, if the test scores of the student teachers better means one of the low ability students are learning problem when the teacher in the classroom and teacher test scores below the mean low ability students largely due to the ability of teachers is also low.

The test results of the teachers test was held on November 24, 2011 at SMAN 1 Soe. Interim analysis that can be described in outline is the most subject teachers UN standard competency was not mastered all predefined. Some teacher background is not in related to the subjects being taught, so that the material given to students was not fulfill the standard that has been standard by the government. There is also a qualified teacher is not a scholar, who has only cognitive ability, and not progressing or not to follow the progress of science and technology materials. They have not been given the opportunity to attend training. Other causes include there was lacking learning resource materials, as well as the difficulty of finding a good book and fit in curriculum. Laboratory infrastructure is also one of the causes of low professional skills of teachers because teachers only learn theory; 
there is no practice the theory in laboratory science and social studies.

The things above can be grouped into 2 main factors namely; static and dynamic factors. For example: the teacher cognitive problems including lack of dynamic factors are factors that can be addressed by the research team as a scientist as dynamic factors, while the static factors are factors that should involve policy makers and school committees, such as the problem of school buildings, laboratories, learning resource book, instructional media etc.. Both of these factors will be described in detail in this section in related to the results of a questionnaire that has been distributed and has been filled by students, teachers, principals and heads of administration. Furthermore, questionnaire of teacher characteristics, distributed and filled in when the teachers working on the test of professional competence. The questionnaire results are tabulated and grouped by subject, Therefore, we can get information about teacher qualifications, teaching experience of teachers, who often used the principle of learning, evaluation models used and the constraints in the delivery of the subject matter.

The data that have been observed in several schools, as well as data that has been conducted focus group discussions, the principal, some teachers and some students and employees found, the implementation of national education curriculum has not been in satisfied conditions this is caused the National exam result is under the national standard. At that time, students' motivation to follow the lesson and how the implementation of learning process in the classroom also in low indicators. All the results of the questionnaire, tabulated to facilitate researchers analyze it. The review classes are also conducted by researchers with the subject teachers UN see teaching in the classroom, so that not all subject teachers UN observable learning. Approximately 10 teachers had already been observed her from 9 schools PBM samples taken.

Focus Group Discussion conducted after all the respondents completed questionnaires were administered by the researcher and the researcher observed after PBM in class by some UN subject teachers. In general it can be stated that, it was often expressed about the lack of schools management in improving teaching facilities in terms of physical (static factors), while the weakness and lack of professional competence of teachers is less exposed, and researchers cannot be opened publicly at the time because of ethics. But the situation can be thought of beginning researchers to find the right solution models of why the UN maple low basic competence in the school.

The next process was done to find solutions to improve quality education in TTS where coordination and harmonization and integration of educational inputs (teachers, students, curriculum, money, equipment, and other matters related) conducted in harmony. It was also some imputes from the teachers to create fun learning conditions that be able to encourage motivation and interest learning of the students, and really be able to empower learners or students. The word "empower" means that learners need to improve the media learning and learning materials, it was also mentioned that there is needed to related the learning materials to students livelihood, and it can be practiced in daily life, and more importantly, learners are able to learn constantly.

Broadly speaking, based on data obtained from the FGD, in-depth interview, observation learning process in the classroom, the teacher competency test, the observation of learning (process standards), the observation standard educational facilities, educational standards and eight observations that have been made in research, can summarized factors that cause students have not mastered the competency standard / basic competence. As per the above description, the factors causing low basic competency examination subjects East South Central High School in NTT is divided into 2 main factors:

\subsection{Static Factors}

Static factors ware some factors related to school infrastructure, and less likely to be addressed by the research team. Data on infrastructure that has been obtained from a questionnaire filled out by the student, teacher, school principal and educational staff (administration). Here is described a static causal factor for each subject in the school examination of samples taken:

- Indonesian language: the schools do not have language laboratory, only libraries with a few literature books that no more than 20 pieces, while there is only some print book for some subjects. Most libraries do not have a story book/legend/novel/short story/magazines, so the student's motivation to read or write an essay is not much. It also causes students still weak in writing specify a paragraph theme, content and other short stories.

- English Language: all schools do not have a language laboratory except SMA PGRI Soe who have English language laboratory, complete with table and his headphones, although only 18 pieces only. In fact there is also a SMAN 1 language lab, but already the last 5 years all tape devices, headphones and other materials and tools damaged because there is no maintenance cost. Nowadays, the table is used as a reading table in the school library. Moreover, in the capital city of Soe as TTS, only a few number of bookstores, and even 
then only sells books, picture books and print books for teaching some elementary, junior high and high school. So if you need a better source book, then it should go to the provincial capital of Kupang, but the purchasing power is still low.

- Mathematics: the unavailability of mathematics instruments and devices in almost all schools except in SMAN 1, but only props cube nets and beams are stored neatly in the box and placed on top of the cupboard the tools of physics. Reference books do not exist at all, only print books for each subject, and then only held by the teacher and some students who can afford to buy it. Almost all schools no checkered boards in the classroom, there is no ruler and protractor from a large timber.

- Physics: from 9 schools sampled, only 4 schools have laboratory science lab. The real conditions of laboratory materials and tools of physics, chemistry and biology are stored in one room. Because the room is only 1 , then of course the number of incomplete laboratory apparatus, even for physics only series parallel circuits, scales and a few simple tools to prove the formula force, motion and others. All such tools exist only in SMAN 1, while 3 other schools, just put up a long table for simple practicum students. For 5 other school, do not have the lab at all.

- Chemical: as same as physics laboratory, only four schools have labs but science lab, and only at SMAN 1 that there are tools and chemicals, while the other three schools did not exist. In SMAN 1 materials chemistry lab rather complete, for chemicals that are very dangerous, just stored in the closet rack only. Similarly, storing them, in a small room no windows, so it is very dangerous to respiratory students and teachers. Even for other 5 schools, do not have a lab at all.

- Biology: from 4 existing school laboratories, all of them do not have the proper tools at the high school lab, there is even a school that only has a torso and a measuring cup just a few pieces. Moreover, the other 5 schools sample, no lab at all.

- Economics: almost all the sample schools do not have adequate reference to the economic book. Only teachers who hold a printed book, the student notes from the teacher as the conventional learning. Owned school library as a reading room, there were few books alone.

- Sociology: the absence of a source book dealing with the subject of sociology, coupled with some background in sociology teacher did not, but history or Civics, so it needs the attention of the Office of District and Provincial NTT.

- Geography: lack of supporting books and geography subjects absence geography lab that had been considered less important by the schools.

\subsection{Dynamic Factors}

Dynamic factor is a causative factor that can be addressed by researchers, such as the ability to factor in the teachers' mastery of subject matter fosterage, classroom issues or problems also use props or physics laboratory instruments, chemistry and biology. Moreover, data on teacher competency of the subjects was brought up to obtained through tests of professional competence held on Saturday September 24, 2011. From the results of the test showed that there are some teachers who have not competency especially in concept of teaching.

There are several concepts that have not met the teacher competency for each subject UN:

- Indonesian language: Teachers were not being able to determine the background of the paper, determine the cause of the conflict, analyzing the structure of a literary topic, and determine the contents of couplets.

- English language: teachers were not capable of to understand synonyms, answering a short reading and meaning of a sentence.

- Mathematics: Teachers are still weak in concept combination, vector projection, the angle between the line and the field, the composition of the transformation, the application of derivatives and integrals and infinite geometric series.

- Physics: Teacher is still weak on the concept of heat, electric field, strong currents, and circuit impedance atomic concept.

- Chemical: Teachers are not able to estimate how much the $\mathrm{pH}$ using the indicator, do not understand the meaning of stretch $\mathrm{pH}$, the teacher does not have adequate ability to balance redox reactions, redox reactions principles and electrochemical, the ability of the teacher is still weak on the concept of reaction rates and calculations, not able explain the concept of equilibrium shift, the teacher was also weak in the material stoichiometry, they also were not be able to estimates using a $\mathrm{pH}$ indicator, do not understand the meaning of stretch $\mathrm{pH}$, the teacher does not have adequate ability to balance redox reactions, redox reactions principles and electrochemical. Moreover, the ability of the teacher were still weak concept of reaction rates and calculations, not able to explain the concept of equilibrium shift, the teacher is still weak in the material stoichiometry and its application. 
- Biology: weak in genetics and invertebrates, not overwhelm cellular respiration, moss life cycle, the process of photosynthesis, less control of the structure of nucleic acids (DNA and RNA).

- Economics: teachers are still weak in the concept of national income, expand production, office supplies, and a function of money, the exchange rate and output balance.

- Sociology: teachers are still weak in terms of describing the activities of the family institution, concrete examples of social interactions, identifying deviant behavior.

- Geography: lack of understanding of the spatial pattern of villages and cities, the basic techniques of mapping, natural resource utilization, dynamics atmosphere change, environmental conservation efforts.

Some teachers who had been observed, was indicating that the majority of teachers still dominate the learning, not student-centered. This is due to the enthusiastic students to ask still lacking. In addition, due to less attractive teacher learning, such as math teachers who teach about the concept of a combination, the combination of the teacher directly and try to explain the formula to calculate the number put in the formula. In addition, there was a lack of meaningful learning, because students are not actively involved in constructing their own formula through a combination of contextual and realistic examples. (Kerans, 2006)

The other drawback is, the problem opportunity for teachers, workshops, training, or the like is very small. Samples of some of the teachers observed, almost $80 \%$ have not completed the training and the like. The above problems, supported again by the difficulty of obtaining a reference book for all subjects, in the absence of a complete bookstore in the capital TTS. The local culture also has an influence, although not too significant.

There are several outcomes that may increase the students performance, the concrete action plan steps are performed in this case was made in the following table.

Table 1. The plan step table

\begin{tabular}{|c|c|c|c|c|c|}
\hline No & Name of Activity & Target & Performance Indicators & Responsible Person & $\begin{array}{l}\text { Working Mechanism and } \\
\text { Scheduling }\end{array}$ \\
\hline 1 & $\begin{array}{l}\text { Management } \\
\text { improvement } \\
\text { MGMPs }\end{array}$ & $\begin{array}{l}\text { MGMPs improving } \\
\text { the quality of the work } \\
\text { program which affects } \\
\text { the binding quality of } \\
\text { learning }\end{array}$ & $\begin{array}{l}\text { MGMPs work program, } \\
\text { refer to the Competency } \\
\text { Standards } \\
\text { Improving the quality of } \\
\text { learning }\end{array}$ & $\begin{array}{l}\text { The team of researchers, } \\
\text { administrators MGMPs, } \\
\text { teachers, supervisors } \\
\text { (department of Education) }\end{array}$ & $\begin{array}{l}\text { Put through coordination } \\
\text { with schools, teachers, } \\
\text { supervisors (department } \\
\text { of Education) } \\
\text { Identification of priority } \\
\text { issues. } \\
\text { Implementation of the } \\
\text { program. }\end{array}$ \\
\hline & & & & & $\begin{array}{l}\text { Coordinate with schools, } \\
\text { supervisors (department } \\
\text { of education) }\end{array}$ \\
\hline 2 & $\begin{array}{l}\text { Monitoring } \\
\text { Improved } \\
\text { Classroom } \\
\text { Learning }\end{array}$ & $\begin{array}{l}\text { Improving the quality } \\
\text { of teaching } \\
\text { monitoring }\end{array}$ & $\begin{array}{l}\text { Schedule monitoring well } \\
\text { structured and } \\
\text { implemented according to } \\
\text { schedule and monitor the } \\
\text { device }\end{array}$ & $\begin{array}{l}\text { The research team, Principal, } \\
\text { Vice Principal of Education } \\
\text { (Curriculum), supervisor, } \\
\text { student representative } \\
\text { Chairman of the classroom. }\end{array}$ & $\begin{array}{l}\text { Preparation of the } \\
\text { monitoring device. } \\
\text { Implementation of } \\
\text { monitoring mith } \\
\text { enhanced monitoring } \\
\text { device }\end{array}$ \\
\hline & & & & & $\begin{array}{l}\text { Evaluation of the results } \\
\text { of monitoring. }\end{array}$ \\
\hline 3 & $\begin{array}{l}\text { Implementation of } \\
\text { Lesson Study } \\
\text { activities }\end{array}$ & $\begin{array}{l}\text { Improving cognitive } \\
\text { abilities of teachers }\end{array}$ & $\begin{array}{l}\text { Reduced teacher } \\
\text { misconceptions about the } \\
\text { subject matter }\end{array}$ & $\begin{array}{l}\text { The research team consists of } \\
\text { lecturers } 9 \text { fields of study }\end{array}$ & $\begin{array}{l}\text { Establish peer team to } \\
\text { execute plan, do and see. } \\
\text { Research team became } \\
\text { one observer and } \\
\text { moderator at the time of } \\
\text { reflection }\end{array}$ \\
\hline
\end{tabular}


Of the three models proposed solution, were expected to assist the school in improving the percentage of KD is still low or not achieved fully. The model can be implemented easily is the first model, which is reviving long MGMPs activities for some cluster schools in South Central Timor regency. The main requirement for implementing the first model is good coordination between the principal, superintendent and school district offices PPO. Therefore, the policy holder will facilitate meetings MGMPs there. While solving the model that is considered new for most people in schools is Lesson Study activities, namely an activity fostering collaborative learning and continuous teacher to help students achieve the indicators in each subject. Privileged Lesson Study is the open class by subject teachers, which can be observed all the citizens of the school and not just any teacher colleagues.

\section{Conclusions and Suggestions}

\subsection{Conclusion}

Based on the above results and discussion, then some of the conclusions that can be drawn are:

(1) Mapping basic competence is not achieved for the last 3 years (school year 2007/2008, 2008/2009 and 2009/2010) for 9 subjects at the high school level of the National Examination South Central Timor indicates that the same difficulties experienced by students for the last 3 years.

(2) Factors cause the static, among others, the absence of a laboratory for science majors, the absence of a laboratory for the Department of English, small amount of library books, no contextual learning media at all.

(3) Factors causing such dynamic, there are teachers who teach subjects not in accordance with its science, almost all teachers have never been included in the training activities and the like, most of the teachers are still doing conventional learning, some teachers give incomplete material the students (some teachers are poorly understood concept, then skipped to not be taught to students), teachers still lack the cognitive abilities because the information about the development of science and technology is very far behind.

(4) Solving models that want to offer is animate as well as increasing the activity MGMPs information to enable the exchange of knowledge among teachers of the same, the implementation of monitoring / mentoring in the classroom in order to follow the creativity of teachers to teach and conduct lesson study in the open class that can also be observed misconceptions or lack of wholeness in learning.

(5) Models monitoring / mentoring and open classes have different, if mentoring, so that monitoring is a research team or school superintendent, but in the open class, peers can also observe, the point is not to judge teachers, just to help teachers provide information of inactivity students in learning.

\subsection{Suggestion}

Further suggestions were proposed by researchers is the sustainability of these results in the form of community service so that the model can be directly planned solution is implemented in schools by involving the community as well as the observer and the person in charge of the course of the educational process around them.

\section{References}

Balitbang. (2010). Application Reports and Statistics National Exam Results 2009. Puspenas, Jakarta.

Balitbang. (2011). Application Reports and Statistics National Exam Results 2010. Puspenas, Jakarta.

Chamidi, S. (2005). Meaning and Application of Simple Indicators of Education, Board of Education and Development, Data Center and Inforamasi Education, Division of Administrative Data and Information. Ministry of National Education, Jakarta.

Garak, S. S. (2006). Difficulty Analysis of High School Mathematics Teacher Kupang Solving Problems In Mathematics Equivalent National Exam. Kupang, Lemlit Undana.

Garak, S. S. (2007). Mathematics Learning Study About Conditions In Some High School in East Flores District graduation rate below $50 \%$ in the National Examination 2005. Kupang, Lemlit Undana.

Kerans, D. S. (2006). Increasing Frequency of misconceptions in Mathematics Learning Approach Konstrukivisme in Class I SMPK Giovanni Kupang. Kupang. Lemlit Undana

Lehmann, H. (1990). The Systems Approach to Education: Special Presentation Conveyed in The International Seminar on Educational Innovation and Technology Manila. Innotech Publications, 20(5).

Moleng, L. J. (2003). Qualitative Research Methods. Rosda Karya, Bandung.

National Education Standards Agency (BSNP). (2009). Reports and Statistics Values Results National Exam Year 2008/2009, the Agency for Research and Development of Ministry of Education. BSNP, Jakarta. 


\section{Copyrights}

Copyright for this article is retained by the author(s), with first publication rights granted to the journal.

This is an open-access article distributed under the terms and conditions of the Creative Commons Attribution license (http://creativecommons.org/licenses/by/3.0/). 